\title{
Peningkatan Prestasi Belajar Matematika dengan Model Pembelajaran Mind Mapping pada Siswa Kelas VIII SMP Negeri Terbuka 1 Gumukmas
}

\author{
Amiliyah Firdausi' ${ }^{1)}$, Eric Dwi Putra ${ }^{2)}$, Lutfiyah ${ }^{3)}$ \\ ${ }^{1,2,3)}$ IKIP PGRI Jember \\ Email : amiliafirdausi94@gmail.com
}

\begin{abstract}
Mathematics learning is a learning flow by teachers who tend to use the teacher center approach. It is the cause of students experiencing difficulties in terms of concepts and main ideas of learning that should be understood, resulting in a lack of students understanding, lazy to take notes. The serious effort needs to be made by the teacher so that there is an increase in student understanding that is done by applying the Mind Mapping learning style. The observation was carried out aiming to explain and illustrate the learning style of Mind Mapping in order to improve the learning performance of eighth-grade students of SMP Negeri 1 Gumukmas with row and series discussion material. In this study, a quality-based or qualitative approach is used, with class action research (CAR). The study began on January 15-29, 2020. Data was collected using observation techniques, questions, and answers, questions, and photographs. Based on the results of the analysis, it was found that the Mind Mapping learning style that can improve students' learning achievement in the material row and series VIII SMP Negeri 1 Gumukmas consists of 6 steps. And the results of observations showed an increase in learning achievement that began in cycle I to cycle II by $25 \%$ and activities in student learning increased by $8,21 \%$.
\end{abstract}

Keywords : Learning Achievement, Learning Model, Mind Mapping

\begin{abstract}
ABSTRAK
Pembelajaran matematika merupakan alur pembelajaran oleh guru yang cenderung menggunakan pendekatan teacher center. Hal ini menjadi penyebab siswa mengalami kesulitan dalam hal konsep dan ide-ide pokok pembelajaran yang seharusnya dapat dipahami, sehingga mengakibatkan kurangnya siswa memahami, malas mencatat pelajaran. usaha yang serius perlu dilakukan oleh pengajar agar terjadi peningkatan pemahaman siswa yang dilakukan dengan diterapkannya gaya pembelajaran Mind Mapping. Dilakukannya observasi memiliki tujuan untuk menjelaskan dan menggambarkan gaya pembelajaran Mind Mapping agar bisa menaikkan kinerja belajar siswa kelas VIII SMP Negeri Terbuka 1 Gumukmas dengan
\end{abstract}


materi pembahasan barisan dan deret. Pada penelitian ini, digunakan pendekatan berdasarkan mutu atau kualitatif, dengan jenis penelitian tindakan kelas (PTK). Penelitian dimulai tanggal 15-29 Januari 2020. Data dikumpukan dengan tehnik pengamatan, tanya jawab, pemberian soal serta foto-foto. Berdasarkan hasil analisis, diperoleh bahwasannya gaya pembelajaran Mind Mapping yang bisa menaikkan prestasi belajar anak didik pada materi barisan dan deret rombel VIII SMP Negeri Terbuka 1 Gumukmas terdiri dari 6 langkah. Dan hasil observasi menunjukkan terjadinya peningkatan prestasi belajar yang diawali siklus I ke siklus II sebesar $25 \%$ serta kegiatan dalam belajar siswa meningkat sebesar 8, $21 \%$.

Kata Kunci : Prestasi Belajar, Model Pembelajaran, Mind Mapping.

\section{PENDAHULUAN}

Hudojo (Putra:2011) matematika merupakan alat untuk mengembangkan cara berpikir. Sejauh ini siswa merasakan bahwa Matematika merupakan mata pelajaran yang tidak mudah untuk di pahami, banyak peserta didik merasa kesulitan dan malas saat akan mengikuti kegiatan belajar matematika, ini dikarenakan materi pembelajaran yang dirasa sulit dan banyak mengandung simbol. kurangnya penguasaan siswa terhadap konsep- konsep Matematika bisa berpengaruh pada prestasi belajar siswa.

Prestasi yang baik dalam hal ini adalah prestasi belajar akan didapatkan melalui pelaksanaan pendidikan yang baik. Kegiatan belajar akan selalu mempunyai hubungan dengan prestasi dalam belajar siswa, karena prestasi blajar merupakan hasil dari proses kegiatan belajar. Prestasi belajar merupakan kemampuan menguasai wawasan juga keterampilan yang dikembangkan oleh mata pelajaran yang lazimnya ditunjukkan dengan hasil tes atau angka nilai yang diberikan oleh guru, Surakhmad (Imaduddin :2012).

Hasil wawancara serta obeservasi terhadap guru Matematika di SMP Negeri Terbuka 1 Gumukmas, ketersediaan buku paket pelajaran Matematika masih belum mencukupi dan tidak sesuai dengan kurikulum, sehingga mengharuskan guru untuk berkreatif dalam memilih materi yang sesuai dengan kurikulum yang berlaku. Satu buku paket Matematika diperuntukan untuk dua orang siswa dan buku tersebut tidak diperbolehkan untuk dibawa pulang, oleh sebab itu masih banyak siswa yang mengandalkan informasi atau materi ajar dari guru, sehingga kegiatan pembelajaran berlangsung teacher center. Kurangnya partisipasi siswa saat kegiatan pembelajaran juga menjadi salah satu penghambat berlangsungnya proses belajar mengajar. Prestasi 
belajar siswa dapat dipengaruhi oleh hal tersebut. Rendahnya prestasi peserta didik dalam belajar bisa dilihat dari data nilai asesmen Matematika peserta didik yang rendah tidak mampu menggapai Kriteria Ketuntasan Minimal (KKM).

\begin{tabular}{c|c|c|c|c}
\hline Nama & \multicolumn{2}{c}{ Daftar Nilia Matematika Kelas VIII } & Rerata \\
\cline { 2 - 4 } & KD I & \multicolumn{2}{c}{ KD II } & KD III \\
\hline Siswa 1 & 54 & 69 & 66 & 63 \\
\hline Siswa 2 & 56 & 65 & 69 & 64 \\
\hline Siswa 3 & 65 & 65 & 62 & 64 \\
\hline
\end{tabular}

Kebanyakan siswa kelas VIII masih banyak yang malas mencatat dan merasa bosan dengan pelajaran Matematika. Untuk memecahkan masalah tersebut, maka perlulah mencari solusi yang tepat dalam aktivitas pembelajaran, dan salah satu solusinya adalah penerapan gaya pembelajaran yang menarik serta dapat membangun semangat belajar siswa terhadap Matematika. Hingga terjadinya peningkatan minat dan kinerja belajar siswa. Dari sekian banyak gaya pembelajaran, terdapat satu gaya pembelajaran yang cocok digunakan serta diaplikasikan dalam pembelajaran Matematika, yaitu gaya pembelajaran mind mapping. Buzan (2005), mengartikan mind map merupakan gambaran perjalanan bagi memori, hingga memungkinkan kita utuk merunutkan dan memetakkan informasi nyata dan pikiran agar cara berpikir alamiah otak dilibatkan sejak dini. Model ini bisa mempermudah anak didik dalam mengingat dan memahami pelajaran yang dipelajari, siswa juga akan mudah dalam melakukan pemetaan pemikirannya terhadap gagasan-gagasan pada materi yang dipelajari. Berdasarkan penjelasan tersebut, agar dapat menaikkan kinerja belajar Matematika kelas VIII SMP Negeri Terbuka 1 Gumukmas, peneliti memfokuskan pada diterapkannya gaya pembelajaran Mind Mapping agar bisa meningkatkan prestasi belajar Matematika dipembahasan barisan dan deret.

\section{METODE PENELITIAN}

Pendekatan yang digunakan adalah penelitian tindakan kelas (PTK) menggunakan pendekatan kualitatif. Sebab melalui pendekatan kualitatif peneliti dapat mengungkapkan makna dan menguraikan data yang diperoleh. (Arikunto, 2009) observasi tindakan kelas merupakan penelitian dimana peneliti melakukan pemaparan 
berkaitan dengan sebab - akibat dari tindakan, menggambarkan tindakan yang diberikan, serta menjelaskan semua proses dari awal pemberian perlakuan sampai dengan akibat yang dikarenakan perlakuan tersebut.

Subjeknya adalah siswa kelas VIII SMPN Terbuka 1 Gumukmas TKB Al Aufa Desa Balung Kidul Kecamatan Balung, terdiri dari 16 anak dengan komposisi 4 laki-laki dan 12 perempuan. Dalam penelitian tindakan kelas, dipakailah model PTK Kemmis \& Mc. Taggart dimana dalam alur penelitiannya melalui step sebagai berikut: (a) perencanaan (Plan), (b) Melakasanakan Tindakan (Act) ,(c) pengamatan (observation), dan (d) Mengadakan refleksi/analisis ( Reflection).

Dalam penelitian tehnik pengumpulan data yang digunakan yaitu pengamatan, yang bertujuan untuk mengerti aktivitas siswa dan aktifitas peneliti sebagai pendidik selama proses belajar mengajar berlangsung. Ada 3 observer yang akan melakukan observasi terhadap siswa dan peneliti, satu orang mengamati peneliti sebagai guru dan dua orang lainnya mengamati aktivitas siswa selama pembelajaran. Interview dilakukan kepada tiga peserta didik yang terdiri dari seorang siswa berkemampuan tinggi, seorang siswa berkemampuan sedang, dan seorang siswa berkemampuan rendah. Selain itu wawancara juga dilakukan kepada guru Matematika dan semua kegiatan wawancara itu dilakukan setelah pembelajaran selesai. Soal yang dipergunakan berbentuk uraian (essay), dan tes dilakukan diakhir (post test). Sedangkan dokumentasi yang digunakan untuk memperkuat hasil penelitian yang mempergunakan model pembelajaran mind mapping pokok bahasan barisan dan deret, data anak didik kelas VIII, kumpulan nilai pra siklus siswa kelas VIII, Rencana Pelaksanaan Pembelajaran (RPP), data instrumen tanya jawab, data instrumen observasi, hasil Lembar Kerja Siswa (LKS) dan hasil tes akhir.

Kriteria keterlaksanaan yaitu: a) kemampuan klasikal, dikatakan tuntas standar minimun 75\% jumlah anak yang mencapai skor $\geq 70$ dari skor maksimal 100 ( standart keutuntasan belajar minimal SMP Negeri Terbuka 1 Gumukmas). b) Daya penyerapan perorangan, dimana diakatakan bahwa seorang anak dinyatakan tuntas apabila telah mencapai skor $\geq 70$ dengan skor maksimal 100 ( standart ketuntasan belajar minimal SMP Negeri Terbuka 1 Gumukmas). 


\section{HASIL DAN PEMBAHASAN}

\section{Hasil Penelitian}

Penelitian tindakan kelas dilakukan dengan dua siklus, setiap siklus dilaksanakan dalam 3 kali tatap muka dan setiap tatap muka ketiga dilakukan tes akhir untuk menakar prestasi belajar Matematika peserta didik. Kegiatan pra siklus yang dilakukan peneliti yaitu bertemu Kepala sekolah dan guru mata pelajaran Matematika. Selanjutnya peneliti melakukan wawancara dan mendapatkan kumpulan nilai yang diperoleh dari guru mata pelajaran matematika, siswa yang mendapatkan nilai $\geq 70$ hanya 3 siswa, artinya presentase ketuntasan di kelas VIII SMP Negeri Terbuka 1 Gumukmas kurang dari 20\%. Kemudian peneliti membentuk enam kelompok, terdiri dari 2-3 orang yang dilaksanakan sebelum pembelajaran dilaksanakan. Objek penelitian merupakan siswa yang berkemampuan tinggi, sedang dan rendah. Kelompok yang dibentuk secara heterogen bertujuan agar siswa saling bertukar pikiran, informasi dan mampu bekerja sama dalam menyelesaikan LKS tentang materi barisan dan deret.

Peneliti meminta 3 validator untuk memvalidasi perangkat dan instrumen penelitian. Validator tersebut terdiri dari 2 dosen pendidikan Matematika IKIP PGRI Jember serta 1 guru matematika SMP Negeri Terbuka 1 Gumukmas. Berikut hasil presentase rata- rata validasi tentang perangkat pembelajaran dan instrument penelitian dari ketiga validator.

\begin{tabular}{lll}
\hline \multicolumn{2}{c}{ RATA- RATA } & KETERANGAN \\
\hline Rata- rata Validasi RPP & $: 94,16 \%$ & Validasi sangat tinggi \\
\hline Rata- rata Validasi LKS & $: 94,22 \%$ & Validasi sangat tinggi \\
\hline Rata- rata Validasi Observasi Aktivitas & $: 92,85 \%$ & Validasi sangat tinggi \\
Guru & & \\
\hline Rata- rata Validasi Aktivitas Siswa & $: 96,42 \%$ & Validasi sangat tinggi \\
\hline Rata- rata Validasi Lembar Wawancara & $: 93,05 \%$ & Validasi sangat tinggi \\
\hline Rata- rata Validasi Tes Akhir 1 & $: 95,36 \%$ & Validasi sangat tinggi \\
\hline Rata- rata Validasi Tes Akhir 2 & $: 98,14 \%$ & Validasi sangat tinggi \\
\hline
\end{tabular}

Berdasarkan hasil uji kevalidan dari ketiga validator di atas, menunjukkan bahwa perangkat pembelajaran dan instrument penelitian telah layak dipakai dipenelitian ini, sebab kriteria hasil validasi sangat tinggi. Setelah semua perangkat pembelajaran dan instrument penelitian telah layak digunakan, maka peneliti 
melaksanakan tindakan pembelajaran. Tindakan pada siklus I memperoleh hasil pengamatan aktivitas guru yang dilaksanakan oleh guru matematika SMP Negeri Terbuka 1 Gumukmas, berikut hasil observasi aktivitas guru oleh observer.

\begin{tabular}{clc}
\hline Pertemuan & Kriteria & Perolehan Observer \\
\hline \multirow{2}{*}{ I } & Skor maksimal & 75 \\
\cline { 2 - 3 } & Skor perolehan & 67 \\
\cline { 2 - 3 } & Presentase & $89,33 \%$ \\
\cline { 2 - 3 } & Kriteria & Baik \\
\hline \multirow{2}{*}{ II } & Skor maksimal & 75 \\
\cline { 2 - 3 } & Skor perolehan & 71 \\
\cline { 2 - 3 } & Presentase & $94,66 \%$ \\
\cline { 2 - 3 } & Kriteria & Sangat Baik \\
\hline
\end{tabular}

Berdasarkan hasil data observer pada aktivitas guru siklus I, menunjukkan bahwa terdapat peningkatan aktivitas guru pengajaran. Penilaian pembelajaran yang berlangsung diperoleh nilai rerata sebesar 91,99\%. Ini dapat didefinisikan bahwa aktivitas guru berada di level sangat baik.

Observasi hasil kinerja siswa oleh kedua observer pada kegiatan disiklus I menunjukkan hasil baik.

\begin{tabular}{clcc}
\hline Pertemuan & Kriteria & $\begin{array}{c}\text { Perolehan } \\
\text { Observer I }\end{array}$ & $\begin{array}{c}\text { Perolehan } \\
\text { Observer II }\end{array}$ \\
\hline \multirow{2}{*}{ I } & $\begin{array}{l}\text { Skor } \\
\text { maksimal }\end{array}$ & 55 & 55 \\
\cline { 2 - 4 } & $\begin{array}{l}\text { Skor } \\
\text { perolehan }\end{array}$ & 43 & 42 \\
\cline { 2 - 4 } & Presentase & $78,18 \%$ & $76,36 \%$ \\
\cline { 2 - 4 } & Kriteria & Baik & Baik \\
\hline \multirow{2}{*}{ II } & $\begin{array}{l}\text { Skor } \\
\text { maksimal }\end{array}$ & 55 & 55 \\
\cline { 2 - 4 } & $\begin{array}{l}\text { Skor } \\
\text { perolehan }\end{array}$ & 45 & 49 \\
\cline { 2 - 4 } & Presentase & $89,09 \%$ & $89,09 \%$ \\
\cline { 2 - 4 } & Kriteria & Baik & Baik \\
\hline
\end{tabular}

Penilaian kegiatan anak didik dalam proses pembelajaran yang diperoleh dari kedua observer mendapat hasil rata-rata sebesar $83,14 \%$. Artinya aktivitas anak didik dalam kegiatan pembelajaran berada pada kategori baik. Setelah melakukan dua kali pertemuan, barulah peneliti melakukan tes siklus I yang dilakasanakan pada pertemuan ketiga hari Sabtu tanggal 18 Januari 2020, yaitu pada pukul 08.20-09.40 WIB. Analisa 
data prestasi belajar peserta didik dilakukan dengan cara menghitung jumlah siswa yang berhasil tuntas pada tes akhir dengan materi yang diberikan oleh guru pada saat kegiatan pembelajaran yaitu Barisan aritmatika dan geometri. Siswa bisa dikatakan tuntas apabila telah mencapai value $\geq 70$. Berdasarkan nilai yang diperoleh dari tes akhir, diperoleh data bahwa sebayak 10 anak telah memenuhi KKM dan 6 anak lainnya masih dibawah KKM. Sehingga presentase ketuntasan klasikal sebanyak 62,5\%, dan dengan kata lain 37,5\% masih dibawah KKM.

Sedangkan hasil pengamatan oleh observer terhadap aktivitas pendidik pada proses belajar mengajar pada siklus II menunjukkan hasil yang sangat baik. Keterlaksanaan model pembelajaran Mind Mapping dapat ditunjukkan dalam bentuk presentase pada tabel berikut:

\begin{tabular}{clc}
\hline Pertemuan & Kriteria & Observer \\
\hline \multirow{2}{*}{ I } & Skor maksimal & 75 \\
\cline { 2 - 3 } & Skor perolehan & 70 \\
\cline { 2 - 3 } & Presentase & $93,33 \%$ \\
\cline { 2 - 3 } & Kriteria & Sangat baik \\
\hline \multirow{2}{*}{ II } & Skor maksimal & 75 \\
\cline { 2 - 3 } & Skor perolehan & 71 \\
\cline { 2 - 3 } & Prosentase & $94,66 \%$ \\
\cline { 2 - 3 } & Kriteria & Sangat baik \\
\hline
\end{tabular}

Didasarkan pada data pengamatan pada kegiatan guru, memperlihatkan aktivitas guru mengalami peningkatan selama pembelajaran siklus II. Penilaian aktivitas guru dalamproses pembelajaran yang berlangsung diperoleh rata-rata sebesar 93,99\%. Ini mengartikan bahwa aktivitas pendidik berada pada kategori sangat baik.

Pengamatan dilakukan oleh kedua obse rver pada aktivitas anak didik dalam kegiatan pembelajaran di siklus II ditunjukanlah hasil yang baik. Hasil dari pengamatan aktivitas siswa yang dilakukan oleh kedua observser pada pembelajaran mind mapping. 


\begin{tabular}{clcc}
\hline \multirow{2}{*}{ Pertemuan } & & Observer I & Observer II \\
\hline \multirow{2}{*}{ I } & Skor maksimal & 55 & 55 \\
\cline { 2 - 4 } & Skor perolehan & 50 & 50 \\
\cline { 2 - 4 } & Presentase & $90.90 \%$ & $90,90 \%$ \\
\cline { 2 - 4 } & Kriteria & Sangat baik & Sangat baik \\
\hline \multirow{2}{*}{ II } & Skor maksimal & 55 & 55 \\
\cline { 2 - 4 } & Skor perolehan & 50 & 51 \\
\cline { 2 - 4 } & Presentase & $90,90 \%$ & $92,72 \%$ \\
\cline { 2 - 4 } & Kriteria & Sangat baik & Sangat baik \\
\hline
\end{tabular}

Penilaian aktivitas dari anak didik pada saat proses belajar mengajar berlangsung yang diperoleh dari kedua observer memperoleh rata-rata sebesar 91,35\%. Artinya terjadi kenaikan aktivitas peserta didik selama proses pembelajaran dari siklus I ke siklus II sebesar 8,21\%. Setelah melakukan 2 kali pertemuan, di siklus II, agar dapat diketahui prestasi belajar siswa terhadap materi Barisan aritmetika dan geometri yang telah diajarkan oleh guru, barulah guru melakukan tes akhir. Tes akhir tersebut dilakukan dipertemuan ke tiga yang mulai dilakukan pada hari Sabtu tanggal 18 Januari 2020, yaitu pada pukul 08.20-09.40 WIB. Diperoleh nilai dari tes akhir di siklus II, diketahui bahwa dua orang siswa masih belum mendapat nilai KKM. Sehingga presentase ketuntasan kelompok pada siklus II adalah 87,5\%, dan dengan kata lain 12,5\% masih dibawah KKM.

\section{Pembahasan}

Pembelajaran model mind mapping dilakukan sebanyak dua siklus dan dilaksanakan sebanyak 6 kali pertemun. Aktivitas guru disaat proses pembelajaran berlangsung dianalisa dengan lembar observasi keterlaksanaan aktivitas pendidik, dimana pada penilaian observasi tersebut memiliki beberapa langkah yang harus dilakukan oleh guru berdasarkan RPP. Guru mata pelajaran Matematika SMP Negeri Terbuka 1 menjadi seorang observer yang melakukan kegiatan observasi dalam hal ini bernama Augusta Yoga Muksiana, S.Pd.

Hasil penelitian, menunjukkan keterlaksanaan aktivitas guru menunjukkan kenaikan disetiap tatap muka, juga mengalami kenaikan antara siklus I ke siklus II. Berdasarkan data penilaian aktivitas guru di siklus I, mendapatkan nilai sebesar 91,99\%. Artinya proses belajar mengajar di siklus I telah dilakukan dengan baik. 
Sedangkan siklus II, nilai rerata observasi guru sebesar 93,99\% dan ada pada kriteria sangat biak.

Berdasarkan paparan data tersebut di atas, maka dapat diketahui kegiatan belajar disiklus I serta siklus II mengalami kenaikan terhadap keterlaksanaan aktivitas guru. Peningkatan tersebut dikarenakan persiapan yang dilakukan guru sangat baik terutama dalam hal perangkat pembelajaran, melaksanakan pembelajaran dengan sangat percaya diri, memberi semangat siswa dalam belajar, dan memberikan bimbingan menyeluruh kepada semua siswa.

Penilaian akhir observasi kegiatan belajar siswa yang telah dilaksanakan kedua observer, Bapak Solihul dan Ibu Huzaimah. Dari hasil pengamatan kedua observer tersebut, menunjukkan nilai rerata pengamatan aktivitas pembelajaran siswa pada siklus I mencapai $83,14 \%$. Sedangkan pada siklus II mencapai nilai rerata sebesar 91,35\%, dan aktivitas belajar anak didik terjadi peningkatan dari siklus I.

Menurut hasil analisis, maka model pembelajaran mind mapping mampu memberi peningkatan aktivitas belajar siswa. Ini disebabkan karena saat proses belajar mengajar, siswa berusaha menemukan serta mencari sendiri konsep yang dipelajari dengan bantuan LKS. Siswa berupaya mengaitkan dan mengembangkan gambaran lebih mendalam, siswa juga diharuskan untuk menerapkan ilmu pengetahuannya dengan mengerjakan lembar kerja siswa secara berkelompok dan mampu menggunakannya untuk menyelesaikan masalah-masalah baru dengan konteks yang juga baru. Selain itu peserta didik juga harus mempertajam daya analisis dan logika siswa dalam pembuatan mind mapping, siswa juga harus mampu memahami dan menghubungkan topik dengan sub-sub topik.

Pada pembelajaran siklus I, aktivitas siswa belum memahami dan belum berpengalaman menggunakan gaya pembelajaran mind mapping, beberapa siswa masih kurang paham dengan model mind mapping, sehingga prestasi belajar siswa masih kurang memuaskan. Pada pertemuan pertama beberapa anak didik yang kurang memperhatikan materi yang dijelaskan pendidik, dan juga masih ada saja peserta didik yang membuat kegaduhan dan berkeliaran ke kelompok tetangga saat membuatmind mapping. Akan tetapi pada tatap muka kedua anak didik mulai kondusif dan paham tentang pembuatan mind mapping. Siswa mulai menikmati pembelajaran yang sedang 
berlangsung. Dari tugas akhir yang dilaksanakan di siklus I, memperlihatkan adanya siswa yang mencapai KKM hanya sepuluh orang.

Sedangkan proses belajar mengajar disiklus II jauh lebih baik dari pada pelaksanaan siklus I. Siswa sudah terbiasa dan mulai beradaptasi dengan gaya pembelajaran mind mapping. Peserta didik mulai mendapatkan kepercayaan diri dalam menentukan pola, bentuk dan warna- warna pada proses pembuatan mind mapping. Siswa juga mampu belajar secara bebas dalam menyelesaikan tugasnya, artinya siswa mulai aktif dalam membangun konsep baru. Siswa juga saling bekerjasama dengan kelompoknya masing- masing, siswa lebih bersemangat dalam menyelesaikan tugasnya dan tidak ada lagi anggota kelompok yang berkeliaran ataupun gaduh saat pembelajaran berlangsung. Pada proses pembelajaran siklus II prestasi belajar matematika peserta didik mulai meningkat, hasil tes akhir yang dilakukan disiklus II memperlihatkan bahwa siswa telah mencapai KKM sebanyak 14 siswa, jadi terdapat peningkatan prestasi disiklus I kesiklus II.

Menurut analisis tersebut bisa diketahui bahwa pembelajaran matematika pada materi barisan dan deret dengan model pembelajaran mind mapping mampu meningkatkan prestasi belajar anak didik kelas VIII SMPN Terbuka 1 Gumukmas. Berikut data meningkatkannya prestasi belajar peserta didik dari siklus I ke siklus II.

\begin{tabular}{cccccccc}
\hline \multirow{2}{*}{ Siklus } & Keterangan & $\begin{array}{c}\text { Nilai } \\
\text { Terendah }\end{array}$ & $\begin{array}{c}\text { Nilai } \\
\text { Tetinggi }\end{array}$ & \multicolumn{2}{c}{ Jumlah siswa } & \multicolumn{2}{c}{ Presentase } \\
\cline { 5 - 8 } & & $\begin{array}{c}\text { Belum } \\
\text { tuntas }\end{array}$ & Tuntas & $<\mathbf{7 0 \%}$ & $\mathbf{2 7 0 \%}$ \\
\hline 1 & Tes akhir & 64 & 78 & 6 & 10 & $37,5 \%$ & $62,5 \%$ \\
\hline 11 & Tes akhir & 68 & 88 & 2 & 14 & $12,5 \%$ & $87,5 \%$ \\
\hline
\end{tabular}

Berdasarkan tabel tersebut, peningkatan prestasi belajar anak didik dari siklus I ke siklus II secara klasikal meningkat sebesar 25\%. Meningkatnya ketuntasan perorangan dapat diamati dari nilai rerata kelas maupun presentase siswa yang tuntas pada kelas tersebut.

\section{KESIMPULAN DAN SARAN}

Model pembelajaran mind mapping, diterapkan agar mampu meningkatkan prstasi belajar siswa pada materi barisan dan deret meliputi 6 langkah, dimana langkah- langkah tersebut dijabarkan pada perangkat pembelajaran yang meliputi III 
tahap, antara lain (1) awal (2) inti dan (3) akhir. Setelah menerapkan gaya pembelajaran mind mapping pada kelas VIII SMP Negeri Terbuka 1 Gumukmas, prestasi belajar anak didik dimateri barisan dan deret dari siklus I sampai siklus II mengalami peningkatan sebanyak 25\%. Dan juga aktivitas belajar siswa juga ada dikategori baik sekali. Hasil rerata kegiatan siswa pada siklus I sebanyak 83.14\% lalu pada siklus II sebesar 91,35\%. Artinya aktivitas belajar siswa pada kelas VIII SMP Negeri Terbuka 1 Gumukmas mengalami peningkatan sebesar 8,21\%.

Bagi pendidik gaya pembelajaran mind mapping merupakan pilihan agar mampu meningkatkan prestasi dalam proses pembelajaran materi barisan serta deret. Agar mampu menaikkan prestasi belajar sisa maka model pembelajaran mind mapping dapat diterapkan dengan membentuk kelompok yang meliputi 3 tahapan (awal, inti dan akhir), dan dalam 3 tahap tersebut terdapat 6 langkah. Guru yang ingin menerapkan pembelajaran mind mapping, hendaknya membuat kisi-kisi penilaian mind mapping sebagai pedoman penilaian. Sehingga, mempermudah guru dalam melakukan penilaian pada hasil mind mapping tersebut.

\section{REFERENSI}

Agustina, Trisia. 2013. Pengaruh Pemberian Bantuan (SCAFFOLDING) Pada Aktivitas Belajar Menggunakan Model Penemuan Terbimbing Terhadap Hasil Belajar Fisika Siswa SMA. Bandar Lampung: Universitas Lampung. https://www.onesearch.id/Record/IOS4198.1729/Preview. diakses 15 Februari 2020.

Aqib, Zainal. 2013. Model- model, Media, dan Strategi Pembelajaran Kontekstual (Inovatif). Bandung : Yrama Widya

Buzan, Tony. 2005. Buku Pintar Mind Mapping. Jakarta: PT Gramedia Pustaka Utama.

Fathurrohman, M. 2017. Belajar dan Pembelajaran Modern. Yogyakarta: Ar-Ruzz Media.

Faelasofi, Rahma.2016. Penerapan Metode Mind Mapping Pada Pembelajaran Matematika. Jurnal e-DuMath.Volume 2 No.2. Lampung. file:///C:/Users/AAA/Downloads/338187386-mind-mapping.pdf. diakses 8 November 2019. diakses 12 November 2019. 
Grasindo. UUD 1945 \& Amandemennya Untuk Pelajar dan Umum. Jakarta: PT Gramedia Widiasarana Indonesia.

Hobri.2009. Model- model Pembelajaran Inovatif.Jember: Center For Society Studies (CSS).

Marxy, Anastasia. 2017. Pengaruh Model Pembelajaran Mind Mapping Terhadap Hasil Belajar Matematika Siswa. JKPM (Jurnal Kajian Pendidikan Matematika), Vol 02. Jawa Barat. file:///C:/Users/AAA/Downloads/2490-66331-SM\%20(5).pdf). diakses 16 November 2019.

Putra, ED. 2011. Pembelajaran Kooperatif Tipe Investigasi Kelompok Untuk Meingkatkan Hasil Belajar Siswa Pada Materi Kubus dan Balok Kelas VIII SMP Negeri 2 Batu. Malang:Universitas Negeri Malang. Tesis tidak diterbitkan.

Wiriaatmadja, R. 2014.Metode Penelitian Tindakan Kelas. Bandung: PT Remaja Rosdakarya. 